\title{
Civilisations
}

Revue internationale d'anthropologie et de sciences

humaines

$60-2 \mid 2012$

Être ou ne pas être balkanique

\section{The Balkans as an Idée-Force}

Scholarly Projections of the Balkan Cultural Area

\section{Diana Mishkova}

\section{(2) OpenEdition}

1 Journals

\section{Electronic version}

URL: http://journals.openedition.org/civilisations/3006

DOI: 10.4000/civilisations.3006

ISSN: 2032-0442

\section{Publisher}

Institut de sociologie de l'Université Libre de Bruxelles

\section{Printed version}

Date of publication: 27 July 2012

Number of pages: $39-64$

ISSN: 0009-8140

\section{Electronic reference}

Diana Mishkova, «The Balkans as an Idée-Force », Civilisations [Online], 60-2 | 2012, Online since 30

August 2015, connection on 01 May 2019. URL : http://journals.openedition.org/civilisations/3006 ; DOI : 10.4000/civilisations.3006

\section{(c) Tous droits réservés}




\title{
The Balkans as an Idée-Force \\ Scholarly Projections of the Balkan Cultural Area
}

\author{
Diana MISHKOVA
}

\begin{abstract}
The bulk of literature on the Balkans which has appeared since 1989 has made a lot of the stereotyped Western discourse about the region during the last two centuries. Local production of regional discourses, on the other hand, has been usually interpreted in terms of internalization of or mirror reactions to the Balkan stigmata. Typically, these studies concentrate on journalistic and ideological discourses, while there have been few attempts at reconstructing the history of the concept of "Balkans" which take into account scholarly and disciplinary discourses. The intention of this article is to confront this void by probing into some of the paradigmatic conceptualizations of the region of Balkans/Southeastern Europe, which had originated in the region itself with regional scholars who had reflected on and attempted to give an answer to the question of what was "common" to and specifically "Balkan" about the Balkans. This historical review finally leads to question the status of the Balkans as a legitimate "mental map" and unit of analysis.
\end{abstract}

Keywords: Balkans/Southeastern Europe, historical region, regionalism, nationalism, balkanology.

Résumé : Le corpus de littérature paru sur les Balkans depuis 1989 a fait grand cas de la production occidentale de stéréotypes sur la région au cours des deux derniers siècles. La production locale de discours régionaux a d'ailleurs généralement été interprétée en termes d'intériorisation et de réactions en miroir au stigmate balkanique. Typiquement, ces études se focalisent sur les discours journalistiques et idéologiques, tandis qu'il y a eu peu de tentatives pour reconstruire l'histoire du concept de "Balkans » qui prennent en compte les discours académiques. L'intention de cet article est de se confronter à ce manque en explorant quelques unes des conceptualisations de la région des Balkans ou de l'Europe du sud-est qui ont émergé dans la région elle-même, sous la plume d'intellectuels et d'académiques qui ont réfléchi et cherché à donner une réponse à la question de ce qui peut être " commun » et spécifiquement "balkanique » aux Balkans. Cet examen historique de la littérature mène à interroger le statut des Balkans comme «carte mentale » légitime et unité d'analyse pertinente.

Mots-clés : Balkans, Europe du sud-est, régionalisme, nationalisme, balkanologie. 
apitalizing on the "critical turn" in the human and social sciences, the mass of literature on the Balkans which has appeared since 1989 has made a lot of the stereotyped Western discourse about the region during the last two centuries. Local production of regional discourses, on the other hand, has been usually interpreted in terms of internalization of or mirror reactions to the Balkan stigmata, occasionally succumbing to clichés of self-defense, which this Western posture has engendered and sustained. ${ }^{1}$ Typically, these studies concentrate on journalistic and ideological discourses, closely entwined with politics, and on the problem of the definition of the region. In this perspective regionalization appears essentially as a political act for political purposes. There have been few attempts at reconstructing the history of the concept of the Balkans which take into account scholarly and disciplinary discourses, if only with the intention to gauge the interferences or divergences between the different modes of conceptualization. This is perhaps not surprising. The scholarly notion of the Balkans is likely to render a more differentiated, nuanced, mutable and disjointed - and as such less "usable" - picture than the one imputed by politicoideological constructions. Methodologically, however, the omission is strange, not least from the point of view of the "Orientalist" critique, focused as it is precisely on unraveling the knowledge-power juncture in the politics of "mental mapping."

The intention of this article is to confront this void by probing into some of the paradigmatic conceptualizations of the region of Balkans/Southeastern Europe, which had originated in the region itself but in relation to intellectual (and political) currents beyond its borders. Regional scholars, whose work will be discussed here, have more or less explicitly reflected on and attempted to give an answer to the question of what was "common" to and specifically "Balkan" about the Balkans. How widely and how deeply shared should the hypothetical common elements be in order to presume their capacity to mold a patently diverse area into a "unitary" cultural-historical region? Which are the distinct "Balkan" traits - geographical/geopolitical, cultural, historical - singling out this region from other regions and lending it a cohesive unity? Many Balkan social and humanist scholars had pondered or touched upon these questions and over a much longer time than present-day transnationalists might make us believe. Their answers were conditioned by a great many factors regarding the disciplinary viewpoint and scholarly paradigms. Bringing this diversity and its implications to light would hopefully move us closer to solving the really serious issues about the Balkans as a legitimate "mental map" and unit of analysis.

\section{Linguistic and ethnographic "Balkanisms"}

For a number of historical-political as well as historiographical reasons, it may be argued that the transnational challenge in Southeast Europe has been stronger and with a more tangible tradition than in other parts of Europe. The imperial frameworks which survived long into the modern era, and the subsequent political problems that this

1. On the Western discourse of 'Balkanism' see Todorova 1997; Goldsworthy 1998. On the local, mainly national, discourses mirroring these Western visions see, for example, Bakić-Hayden 1995; Duțu 1999; Trendafilov 1996. 
inherited cultural diversity bequeathed to the successor states, provided a distinctive context, where local social sciences took shape. It also brought the incentives to go beyond national borders - in the pursuit of either irredentist or conciliatory policies and scholarly schemes.

The challenge was at first taken up by linguists, literary scholars, and ethnographers, while historians - to the extent that they ever, prior to World War II, ventured beyond the national framework of history - largely followed and emulated their methods. The period between the mid- $19^{\text {th }}$ and early $20^{\text {th }}$ century was a time of systematic accumulation of "positive" "fragmented" knowledge, where the institution of the Landesmuseum set a "best-practice" pattern, and of a boom in the publication of "sources" in history, linguistics, ethnography, and archaeology. Altogether, there was a certain fear of and reluctance for generalizations - a prudence that was characteristic of the age and cultivated by positivism. Historians, in particular, basically remained confined to a vision of contributing with some bricks to the edifice of a national history to be erected in the distant future. Remarkably, external historical interest in the region was compartmentalized in a similar way. The Czech Konstantin Jireček's Geschichte der Bulgaren (1876), which is celebrated as laying the foundation of modern Bulgarian historiography, was followed by the no less fundamental Geschichte der Serben (1911). The English historian William Miller wrote his Southeast-European collection in 1896, tellingly entitled The Balkans: Roumania, Bulgaria, Servia and Montenegro (reedited in 1899 and 1908), while publishing a separate volume on the History of the Ottoman Empire in the Cambridge World History series.

Interestingly, the period around the turn of the century, generally characterized by the radicalization of national discourses and the emergence of anti-liberal nationalism, came to be also influenced by the emergence of schools of non-national methodology. This trend capitalized on the rise of comparativist methodologies, constructing a sort of Southeast-European (Balkan) unit of analysis. Although the terms "Balkans" and, more rarely, "Southeastern Europe" appeared at the beginning of the century, it seems to have been initially used, next to geographers, mainly by scholars interested in comparative linguistics and ethnography, especially in common elements discovered in the languages and folklore of the region (Drace-Francis 2003: 277). ${ }^{2}$

In this respect, the central role of German educational and research institutions - with Leipzig (comparative linguistics, folklore and ethnography - Weigand and Leskien, Lamprecht, Wundt), Berlin (Archiv für slavische Philologie), and Munich (Byzantine studies, Byzantinische Zeitschrift) at the forefront - deserves mention. In Leipzig August Leskien (1840-1916) held a chair of the department of Slavic philology during forty years and was considered, by Bulgarian commentators at least, "a teacher of all our outstanding Slavists" (Iordanov 1938: 62). Gustav Weigand (1860-1931) acted as a similarly powerful authority - a linguist and a fervent champion of the comparative study of Balkan linguistics and ethnography, which he

2. The terms "Turkey in Europe" or "Balkan peninsula" were also used, alternatively or in parallel, at the time.

3. Leskien was an authority in Slavic linguistics and in Old Bulgarian - "altbulgarischen (altkirchenslavischen) Sprache" - as the language of the Glagolic and Cyrilic monuments. 
saw as forming one intermingled space through long-term interaction. He founded the Institute for Romanian Language (1893), later transformed into the Institute for Balkan Languages, which focused mainly on comparative Balkan linguistics and folklore. His Ethnographie von Makedonien (Leipzig, 1924), where he searched for the sources of the ethnic and linguistic diversity in Macedonia, has become a blueprint for Balkan ethnography and, at the same time, a key reference in the Bulgarian national narrative of Macedonia. ${ }^{4}$

The upsurge in comparative linguistics was closely linked to some of the earliest attempts at identifying what is now known as the Balkan linguistic union (or "linguistic area," Sprachbund) - "the first area of contact-induced language change to be identified as such" and the model prototype for language contact, interaction and convergence (Friedman 2007: 201). ${ }^{5}$ Indeed, linguists first used the term "Balkanism" to indicate a lexical and, more indicatively, grammatical "feature shared among the unrelated or only distantly related languages of the Balkans" - Balkan Slavic, Balkan Romance, Albanian Greek and Balkan Turkish dialects, which they attributed to either a common substratum or communal multilingualism and contact-induced change. Linguistic Balkanization', i.e. the creation of a relatively unified linguistic area owing to centuries of multilingual contact, is thus the very opposite of political 'Balkanization' as fragmentation (Friedman 2007: 202) conveying exclusively negative connotations (M. Todorova). Such similarities among the Balkan languages were first observed by Jernej Kopitar (Kopitar 1829) and Franc Miklošič (Miklosich 1861), ${ }^{6}$ and in time came to be increasingly interpreted as testimonies of "centuries of multilingualism and interethnic contact at the most intimate levels" (Friedman 199495: 89$){ }^{7}$

The establishment of Balkan linguistics as a subdiscipline within linguistics in the 1920s went hand in hand with basic syntheses and theoretical formulations that still inform the field (Friedman 2006: 659). As late as 1929, the then leading Romanian

4. These institutes/courses/seminars/chairs together with the Leipzig-based Slavic Academic Society (1878-1898) became platforms for intra-regional transfer: in the Institute for Romanian Language, Bulgarians studied Romanian language and history; the goal of the Slavic Academic Society" was "the rapprochement among the Slav students living in Leipzig for the purpose of exploring the life, literature and history of the Slav peoples," while political and social issues were excluded from the discussions.

5. "In modern terms, a sprachbund is understood as two or more geographically contiguous and genealogically different languages sharing grammatical and lexical developments that result from language contact rather than a common ancestral source" (Friedman 2006: 657).

6. J. Kopitar's characterization of Balkan Romance, Balkan Slavic, and Albanian as "drey lexikalisch verschiedenen, aber grammatisch identischen Sprachen" ("three lexically distinct but grammatically identical languages') - which he attributed to the influence of a Thraco-Illyrian substratum - is taken as the earliest indication of the Balkan sprachbund (Kopitar 1829: 106). Miklošič focuses on the relationships of Balkan Slavic and Romance (Miklosich 1861: 6-8).

7. The original formulation of the concept of 'lingustic area' is attributed to the Russian linguist N.S.Trubetzkoy (1923: 107-24). Trubetzkoy argued that the "theory [of a common linguistic substratum] is not sufficient to explain the coincidences between languages of different genealogical families" (Trubetzkoy 1933), thus stressing the importance of language interaction and contactinduced change. 
historian Nicolae Iorga would still find it instructive to draw historians' attention to the positive tradition set by philologists, who, "in this respect [of highlighting the common characteristics of Balkan languages], had surpassed the historians," and to recommend to the latter "to operate in the way philologists had long been doing by dealing with all Balkan languages." (Iorga referred specifically to Gustav Weigand and the Danish linguist Kristian Sandfeld [1873-1942]) (Iorga 2008 [1929]: 14-15). ${ }^{8}$

Comparative folkloristics and ethnography developed simultaneously with comparative linguistics. A leading practitioner and a champion of what we would call today the "history of cultural transfer" at the turn of the $20^{\text {th }}$ century was August Leskien's disciple, the Bulgarian ethnographer and literary scholar Ivan D. Shishmanov (1862-1928). Shishmanov considerably expanded on the assumption of crisscrossing Balkan (poetic) cultures that was originally developed in Leskien's Fairytales from the Balkan lands (Leskien 1925), and was among the first to talk about les savants balkaniques and of the need for communication among them. In the spirit of the critical post-Romantic method he dispelled the notion of the autochthonous roots and the uniqueness of "national folklore" (as propagated by what he dubbed "patriotic romanticism"), and instead charted a vast global network of exchange - 'internationality' - of beliefs, tales, epic traditions and popular lore. He came to what were then the unconventional conclusions that,

The existent researches suffice to persuade us that we should stop regarding the popular lore of any single people as its totally original creation. There had been borrowings since time immemorial. ... The originality of a culture often lies in nothing other but its more or less self-reliant remaking of the borrowed foreign elements. Peoples - small and big - are great plagiarists. (Shishmanov 1965: 373)

Shishmanov thus undercut the romantic notion of national uniqueness and exceptionality that precluded the quest for resemblances in the development of nations. For him, all these interactions and mutual borrowings were possibly due to the similarities in the development of individual nations. These 'transfers' and 'entanglements,' to put it in the present-day transnationalist vocabulary, riveted the very fabric of a people's wisdom and were paralleled by those characterizing what Shishmanov defined as the "patriotic period" in the study of the folk. At that time, forged claims to national authenticity appeared as "some kind of vital law that implacably displays itself at the beginning of each scientific revival" (Shishmanov 1966: 7-22).

In some of his most authoritative comparative studies, such as The Song about the Dead Brother in the Epic of the Balkan Peoples (Shishmanov 1966: 62-215), Shishmanov took on to trace meticulously the itinerary of popular folk themes and their local variants, whose diffusion outlined a cultural-historical area. He thus set himself "the task of making not only a contribution to comparative folklore, comparative

8. See also Gustav Weigand (Weigand 1925) and Kristian Sandfeld (Sandfeld 1930). Sandfeld attributed almost all the commonalities of the Balkan sprachbund to the influence and prestige of Byzantine Greek. Other linguists saw these commonalities as the result of the influence of the Thraco-Illyrian substratum (Kopitar), the Balkan Slavic (K. Leake) or Balkan Latin (G. Solta). 
literary history in particular, but also a small contribution to the demopsychology of the Balkan nationalities" (Shishmanov 1966: 147). Of interest to us here are two particular outcomes of Shishmanov's painstaking investigations.

First, the 'cultural space', which his comparative studies charted, was a zone defined by interaction and internal migrations of popular themes with considerable local variations rooted in specific historical contexts. The cultural-historical geography thus drawn cut across the geographical boundaries of the region, the administrative borders of empires and the cultural ones of religion. The genesis of the plot about the dead brother was found to be in ancient Asia Minor, from where it had spread to the Balkan populations south of the Danube; that folk theme was missing in the lands of the Romanian kingdom (Regat) but its Romanian variants could be encountered in Bukovina (where, Shishmanov surmised, they had been transferred by Bulgarian migrants). At the same time, the reciprocal North-Central European plot about the dead fiancé (Lenorenstoff, which became extremely popular in the $19^{\text {th }}$ century through Gottfried August Bürger's poem 'Lenore'), was found to be nonexistent among the Bulgarians, the Greeks, the Arumanians and the Albanians, but could be encountered among the Serbo-Croats and in the Romanian kingdom. So, rather than being defined by cultural faultlines, the Balkan ethnographic region stood wide open to both the East and the West, while its internal geography was carved into variously shaped, movable 'ethnographic sub-areas' - some overlapping with, others excluding, parts of the 'geographic', 'linguistic' or 'historical' Balkans.

Secondly, notwithstanding the intensity of exchange and the similarities within this historical zone, Shishmanov stopped short of devising a notion of a 'Balkan culture' or 'Balkan demopsychology' defined by particular features, if not stable boundaries. Setting off from the assumption about the immanent and global interconnections between cultures, Shishmanov does not appear to have been keen in distinguishing between intra-Balkan and inter-Balkan "borrowings." To his ethnographic perspective, however, it was obvious that interconnection and exchanges were especially intense and traceable between neighbouring countries of similar development levels. Shishmanov's implicit understanding of the region thus appears to have been one about a fluctuating space of cultural osmosis based on long-standing co-existence, interaction and percolation. Significantly, the agencies and the driving forces behind this (regional or global) process were the national cultures.

Folklore, Shishmanov tells us, is the "people's science," the "science of the poor in spirit" which allows us to "probe deeply into the soul of the folk, to get to know its outlooks and the ideas driving it, the notions it had generated or inherited or borrowed, and the ways in which all these had been transformed in its consciousness: how they had changed, which particular form they had taken in contrast to the notions of other peoples, etc." (Shishmanov, 1966: 23). Ultimately, the important question appeared to be "what influence all those numerous races, which had been in contact with us in the course of history, had exerted on our national type, on our culture, our customs, our language. That means to examine all foreign components of our nationality, culture, 
language, etc." (Shishmanov, 1966: 268). Indeed it befell ethnography ${ }^{9}$ to perform what he saw as "a cardinal political task," for "folklore studies are the sole instrument for defining the ethnographic boundaries of the various Balkan peoples" (Shishmanov 1966: $30-31) .{ }^{10}$

Thus, while conceding that national isolation did not exist and that each culture evolved in a process of continuous exchange with other cultures, Shishmanov's 'comparativism' pursued above all the identification of the "foreign elements" and "borrowings" in the national makeup. The organizing agency and the key reference remained the nation. Shishmanov never identified that which ultimately defined a nation's individuality (and its "ethnographic boundaries") so that it could participate in an exchange with other nations, the "core' that lay beneath all the "foreign" impacts and proved able to assimilate them while remaining the 'same' national individuality. But it was clear that such an ethnocultural hub did exist, it represented the actual agency of history, and its thorough exploration was the scholar's chief duty - "in order to understand the direction in which the nation had evolved and to chart the direction of its future development in the best possible sense" (Shishmanov 1966: 23).

This 'double-scaled' ethnographic vision was not without match elsewhere in the region. Drawing on his investigations of medieval history and literature, the Romanian philologist and historian Ioan Bogdan (1864-1919) made a name for himself by insisting on and seeking to demonstrate the significance of the Slavic studies for the Romanians. He agreed with Shishmanov in arguing that the Romanians, much like the Bulgarians, could not gain a proper understanding of their national history unless they perceived of their culture in its connectedness with other national cultures in the region. At the same time, again in full accord with Shishmanov, he saw the duty of cultural history to undertake a solid examination of the nation from an ethnographic and statistical point of view in order "to account for the constitutive elements of our nationality and to understand its nature and inclinations" (Bogdan 1905: 20). In both these cases one can clearly detect the close connection between comparativism and the national framework of analysis.

Yet awareness of, and research into, the Balkan linguistic community and folklore/ ethnography were the first, and for quite some time the only, areas in which the idea of a Balkan historical commonality thrived. The notion of a Southeastern Europe, as far as it surfaced in academic discourse, stood for a cultural koiné rather than a historical region. It was in the heat of and mainly after the large-scale transformations wrought by the two Balkan wars and World War I that other disciplines and other visions of the nature of the regional commonality will play in the debate and reformulate the concept of Southeastern Europe.

9. As a "systematic enquiry" of folklore, ethnography, according to Shishmanov, involved "literary history, on the one hand, and ethnology and popular psychology, on the other, that is the natural and the cultural history of a people" (Shishmanov 1966: 23-24).

10. Corroborating the Bulgarian nationality of the Macedonians was a key target of this research program. 


\section{Anthropogeographic and ethnopsychological structure of the Balkan Peninsular}

The pre-eminence of linguistic and folklore comparatism at the establishment of Balkan studies had some immediate and some long-term consequences. Among the most durable was the association of "Balkanology" primarily, sometimes solely, with ethnology and linguistics - a narrow reading that has survived until today. ${ }^{11}$ In its own time, this disciplinary approach impacted regionalist research in two opposite directions. On the one hand, the commonalities in grammar, syntax, belief, and popular lore seemed to imply an underlying primeval unity in the way of thinking, mentality and the unconscious. This trend evolved simultaneously with the upsurge of psychological discourses first in Germany and then in France. But since the latter were dominated by the disciplines of Völkerpsychologie (or comparative folk psychology) and national characteristics, the result usually was to underwrite rather than subvert and relativize national fragmentation. ${ }^{12}$

For Shishmanov, as we could see, comparative folklore was a key to grasping the "demopsychology of the Balkan nationalities," not some common "Balkan mentality." But the prominent place in conceptualizing the Balkans as an area of infinite diversity and continuous interaction undoubtedly belongs to Jovan Cvijić (1865-1927) - "the founder of Balkan geology, geography and anthropogeography" - indeed of, as the next generation of regional scholars would argue, "Balkanistics" proper. ${ }^{13}$

Significantly, Cvijić spoke of the Balkan Peninsula - a term he definitely preferred to "the Balkans" and never used interchangeably with Southeastern Europe. Moreover, while his geomorphological observations encompassed the whole Peninsula, his psychological investigations concerned only the South Slavs. The Romanians, Turks,

11. See, for example, the definition on http://wapedia.mobi/de/Balkanologie, and that of the Zeitschrift für Balkanologie: Die Balkanologie ist eine Teilwissenschaft von Ethnologie und Linguistik, "deren Ziel es ist, die Kulturen auf der Balkanhalbinsel in ihren sprachlichen und außersprachlichen Manifestationen ethnien- und sprachfamilienübergreifend, vergleichend und interdisziplinär-integrativ zu untersuchen" (http://www.zeitschrift-fuer-balkanologie.de/index2. htm; http://www2.uni-jena.de/philosophie/slawistik/ztsrbalk.htm ), last accessed on $20^{\text {th }}$ December 2010.

12. We should also note that the need for clearer ethnocultural definition at the turn of the $20^{\text {th }}$ century was intimately linked with the rise of ethnopsychology which was spurred not only by advancements in social psychology but also by historians like Lamprecht, Ranke and Burckhardt. This in turn presupposed an effort at characterological definition on a comparative scale. It is not surprising at this background that preoccupation with ethnopsychology and its comparativist methodology came to unite the three otherwise rather divergent "Balkanists" of the late $19^{\text {th }}$ and early $20^{\text {th }}$ century - Shishmanov, Cvijić and Iorga.

13. The results of Cvijić's immense work on the human geography of the Balkans and his conceptions in this domain were summarized in his famous La Péninsule Balkanique. Géographie humaine, first published in French (1918) and translated in Serbian in two volumes as The Balkan Peninsula and the South-Slav Lands. Basics of Anthropogeography. I (1922), II (1931). La Péninsule Balkanique is celebrated by the "geographical craft" as "one of the great regional geographies of its time" (Freeman 1967: 192). Cvijić's research has had a profound impact on geographical and ethnographical thought and practice, in and beyond the Balkans. 
Greeks, Albanians and Vlachs were not part of Cvijić's ethnopsychological map of the Balkans.

One of the most striking features of Cvijić's anthropogeographic map of the Balkan Peninsula is its rigorously taxonomic character. It revolved around numerous classifications concerning geographic regions, geomorphological and physical features, civilizational (or cultural) zones, types of settlement, and psychic types. This intimated a vision of great structural and cultural diversity over time and space effected by causes of various order - geographical, historical (political), social, ethnic. ${ }^{14}$

Cvijić divided the Balkans into four cultural zones: modified Byzantine (Old Balkan) civilization "Balkanism in the true sense of the word;" zone of the Turkish and Eastern ("Turco-Oriental") influences; zone of the Western and Central European culture; and patriarchal cultural zone. Noteworthy is Cvijić's assertion, that "The most pronounced boundary in this region is not the boundary between Byzantine and Western civilization [as it was usually thought] but that between the patriarchal regime and the Byzantine civilization" (Cvijić 1918: 481; Cvijić 1922: 87-88). Moreover, Cvijić saw the historical development of the Balkan peoples as being marked by discontinuities and assimilations between different clusters of cultures. "The lack of continuity of the civilizational influences is a characteristic of the Balkan Peninsula, a condition the reverse of that which obtained in Western and Central Europe" (Cvijić 1922: 471). In the end, what one is confronted with is a palimpsest of considerably modified, partly overlapping and largely circumscribed civilizational zones.

Virtually coinciding with these zones of civilization were Cvijić's psychological types: Dinaric, Central, Eastern Balkan (Bulgarian) and Pannonian. While I cannot elaborate here on the characteristics attributed to these four psychic types or on the foregrounded primacy with which Cvijić endowed the Dinaric type, one aspect deserves mention. ${ }^{15}$ The notion of a "Balkan mentality," both as a generalized regional and as an ethnic category, has long been duly criticized. Its local diffusion has been attributed to dubious academic popularity external to the region penchant for portraying the Balkan cultures as a sanctuary of patriarchal practices and life-styles long-extinct elsewhere in Europe. As a matter of fact, however, Cvijić was the first to implement this "scientific" approach to the Balkans. Scholars of note like Gerhard Gesemann, perhaps the most powerful voice among the interwar German "folk psychologists" of the Balkan Slavs, might have gone a step further in supplying Cvijić's psychological and folkloric interpretations with racial underpinnings. But neither the discipline of Balkan folk psychology nor the genre of "heroic lifestyle" as an epitome of the true Balkanness and of homo balkanicus were his inventions. Indeed, Cvijić's scholarly reputation itself appears to have lent respectability both to the "regional relevance" of the discipline and to the conclusions of as different and (in their own way and

14. Although stressing the preeminence of geography, Cvijić was not a naive geographical determinist. He argued that, "Next to the geographic, three groups of historical and social factors have strongly impacted the ethnographic and anthropogeographic phenomena in the Balkan Peninsula. These are the historical events, the zones of civilization and the migrations of peoples and ethnic groups" (Cvijić 1922: 69; italics in the original).

15. On the debate between Cvijić and the Croatian anthropologist Dinko Tomašić regarding the Dinaric-Pannonian, resp. "highlander-lowlander" opposition, see Živković 1997 and Kaser 2003. 
scholarly tradition) salient regionalists as Gesemann and Fernand Braudel, both of whom drew heavily on Cvijić's ethnopsychological typology (Gesemann 1943; Braudel 1995: 776-780).

Finally, against the doctrine of racial purity, Cvijic maintained that racial intermixture had occurred everywhere in the peninsula, and in certain areas at least nationality was variable and uncertain. But this somehow did not subvert what he typically saw as the divergent, irreconcilable and often antagonistic ethnic identities (the Yugoslavs being a partial exception to this rule). On the contrary, the ontological fragmentation ultimately sealed the impossibility of a Balkan cultural convergence and unity and, by extension, of a unitary concept of the Balkans - not only in Cvijić's present, but also in the Balkan past.

All in all, Cvijić's conceptualization of the Balkans may be seen as foundational for the later-day visions in at least two directions. Firstly, he brought to the fore and scientifically underpinned the inherent multidimensional diversity of the region, which thus became constitutive of the region's specifics. Cvijić reformulated what had been typically seen as an "ethnographic museum," into a complex structure of geographic, historical, cultural, social and economic intraregional variations whose combination, somewhat paradoxically, turned into "unifying structural characteristics" of the region. It should be noted that this vision of the region will thenceforth evolve in parallel to the unitary one. "Up to our day," Joseph S. Roucek maintained in 1939, "the Balkans have remained a striking example of disunity - geographic, ethnical, linguistic, religious, cultural and political" (Roucek 1939: 1). In his History of Southeastern Europe (1950) Georg Stadtmüller warned: "We should nonetheless be wary of the dangerous and misleading notion, that it [the term Southeastern Europe-DM] implies a peculiar unity of the space thus denoted. The space of Southeastern Europe is rather marked by internal diversity and differentiation as no other part of Europe is" (Stadtmüller 1950: 14). The problem had been already raised by Fritz Valjavec in the 1930s when registering the lack of "at least to some extent unitary research area and unitary concept of Southeastern Europe" (Valjavec 1941: 11). Valjavec himself, however, left the question open: for him Southeast-European studies were a methodical "complexio oppositorum" (bringing together a wide range of simultaneously applied disciplinary methods), where Southeastern Europe serves above all as a "working concept" (Arbeitsbegriff), but where the "unity of Southeastern Europe" is not a working prerequisite for the studies of the South-East (Valjavec 1942: 5).

Cvijić's notion of the Balkans is foundational also on account of elaborating the connection between nature and culture - a connection that, again, will be played out in different registers, especially during the interwar period. His major contribution to the inquiry of the region, from an anthropological point of view, is that he was the first to define a historical geography of the Balkan man. From the point of view of history, it was the realization and the demonstration that written sources were not the sole, and in his case not even the primary, building material of the historical narrative about the region. But he did not construct, on this basis, a regional cultural or historical specificity, a discrete civilizational 'Balkan type.' On the contrary: his empirical studies framed an area which, albeit characterized by considerable demographic interconnections and cultural overlapping, did not evolve and stabilize into a more or less unitary cultural-historical space. Nowhere did Cvijić try to define any uniform 
characteristic features or attributes of the region as a whole. His interest seems above all to have been, not identifying an overarching commonality, but highlighting the internal diversity, complexity and heterogeneity of the region. ${ }^{16}$

Was anything holding the region together, that could define it as an analytical whole? Cvijić did not directly confront this question yet his writings intimated a few answers.

At a certain level, Cvijić's "regional scale" of observation itself seems to have sketched the region as a unit defined by the scope of interaction. Cvijic himself designated it as the "Balkan peninsula" even if, for reasons of his own, he included in it large parts of the Pannonian plane and excluded the Romanians.

More substantially, one can detect in his research certain directions - and an underlying argument - that prioritized some tendencies over others. He distinguished what is recurrent, typical or showing the potential to become a dominant regional "type" amidst the huge variety of trends, local conditions and idiosyncrasies.

Mobility or migrations - or what Cvijić called metanastasic movements in particular stand out as a powerful vehicle of intra-regional "penetration and connection," continuously and effectively subverting the centrifugal tendencies. They allowed the expansion of certain civilizational zones, respectively (ethno-) psychological types, over bigger parts of the peninsula thus overpowering the weight and the effects of cultural fragmentation. Metanastasic movements, and the zones they came to form, are what ultimately defined the prevailing civilizational and ethnodemographic profile of the region. Over the long run they tended to create, not a relatively homogeneous regional historical and cultural space (as Iorga would have it), but smaller or bigger homogeneous ethnic, psychic and civilizational enclaves which, with regards to their relative strength and scale, were hierarchically ordered. Hardly surprisingly, the Serbs stood out as the most populous and dynamic force behind these movements - the vibrant Balkan metanastasic population par excellence. ${ }^{17}$ Around this Serbian (later Serbo-Croatian-Slovenian) core the region's internal "centre" was supposed to emerge with the potential to neutralize, even reverse, the centrifugal tendencies resulting from its diversity. Cvijić, as a matter of fact, came up with a geopolitical theory, drawing on the conjunction of geomorphologic and geophysical analysis with human geography and migrations. This theory gave a central political and strategic role to "Greater Serbia" as ordained by geography and being in the interest of the West. History thus became subordinated to a geopolitical and ethnocultural framework. Eventually the regional narrative is not anti-national, on the contrary, it was meant to buttress Yugoslav nation-building, where the common racial characteristics overwrite the diverging historical, religious and social experiences.

16. Some critics went as far as to blame Cvijić that he had deliberately stressed the geomorphological and geophysical diversity of the Balkans in order to create geographical justification for the existing national states and undermine the idea of a Balkan unification (Ćorović 1937: 9-11).

17. "The above survey indicates that metanastasic movements were of different kind and more intensive among the South Slavs of the western and central regions than among the Bulgarians. Among the former the Serbs had embarked on much more significant metanastasic movements than the Croats and the Slovenes" (Cvijić 1922: 111-112). 
As an area of continuous interaction between distinct and tangible 'ethnicities' and 'types', Cvijić's notion of the Balkans resonates in a sense with Shishmanov's. At the same time, his understanding of the features that came to characterize the Balkan Peninsula is in many ways at variance with Iorga's. This is noteworthy on two counts. First, both of them were usually revered as the quintessential founders of "Balkanology" in the same breath; second, the historical framework and the cultural phenomena they referred to in their interpretations were almost identical, but their conclusions were rather different.

\section{Byzance après Byzance: the cultural-historical entity of Southeastern Europe}

The incorporation of a national history in a universal history, thence the search for a larger, integrative cultural or civilizational space, had figured high on the historiographic agenda ever since the institutionalization of history in the Balkan states. For most of the $19^{\text {th }}$ century, that space was the Western world. From around the beginning of the $20^{\text {th }}$ century, alternative spaces, such as those defined by genealogical affinity (e.g. the Slavic world) or with which the nation happened to be in direct and permanent interrelations, began to be more systematically promoted as possible mediators for broader integration.

This trend and the call for non-national historical methodology radiating from Leipzig - especially from Karl Lamprecht - converged in the work of Nicolae Iorga (1871-1940), the most prominent Romanian historian of the first four decades of the $20^{\text {th }}$ century. Iorga went much further than Shishmanov and Cvijić ever did in envisioning a sort of Balkan commonality, historicity, phenomenology and culture. This harmonized with his predilection for the new cultural history which, as he wrote, "concerns above all what is deep, fundamental and general in human life." Iorga was most inclined to build his synthesis on the basis of collective psychology and a belief in culture as a binding force and a principal instrument of any ecumenicity. His vision of the area's specificity and mission reflected a distinctive relationship of national, regional and global scales of historical experience.

Already in 1914, in his inaugurating speech for the Institute for Southeast-European Studies in Bucharest, which he had founded the year before, Iorga made a plea for the study of the "history of great territorial units, ... of the great currents of civilization and the spiritual condition which these units create, of the durable social forms which they succeed to crystallize" (Iorga 1914: 42) ${ }^{18}$ By that time he had already published his first synthetic works as advocated (in fact inspired) by Lamprecht: Geschichte des Rumänischen Volkes (2 Vols., 1905) and, heralding his regional syntheses, Geschichte des Osmanischen Reiches nach den Quellen dargestellt (5 vols., 1908-13), in which he exposed the emotional nature of conceiving of the Turks and their empire as an historical anomaly detrimental to civilization, and proposed the study of Ottoman history as an integral part of world history.

18. Iorga himself made no secret of the political underpinnings of the Institute: the establishment of such an institute in Bucharest was a legitimate "affirmation of Romania's rights" as a major regional player (Iorga 1911: 20). 
Iorga was by no doubt the first regional historian to grasp the significance of a common heritage. The scope, and underlying contents, of his notion of "Southeastern Europe," in outspoken opposition to the Balkans and the Balkan Peninsula, deserves special attention. Indeed, we may speak of a radical re-configuration following Iorga's observation that "peoples are not in the least defined by the region on which they lean or by the region in which they are placed but by the region towards which they look" (Iorga 1935: 108). By this criterion of orientation, ordained by geography and history, the Rumanians were a "Carpathian people," a "Danubian people" and a "people of the right bank of the Danube," the Greeks were a "Mediterranean people," the Turks a Central Asian one, and the Yugo-Slavs belonged to different regions; the Bulgarians were the only impeccably "Balkan people" but they too sought to break free from their land-locked position by reaching out to the Black Sea and the Adriatic. The geographical term Balkans, therefore, was "inaccurate [and] unjustified; there exists no element on which it can lean" (Iorga 1935: 107-110; Iorga 1940: 6-8). Iorga never explained in what way the alternative term of Southeastern Europe was better suited to integrate these various orientations. But it certainly fulfilled another salient desideratum: unlike the Balkans, the region of Southeastern Europe, in Iorga's reading, could capture the integral space of "Eastern Romanity": the "Carpatho-Balkanic" or "Carpatho-Danubian" realm incorporating the Romanians with the once Romanized inhabitants (the Vlachs) to the south of the Danube, i.e. in "the Balkans" proper (Iorga 1999: 122-125, 135-137). This was the semantics underlying, what he called, "our people's balkanism."

Its outgrowth was the notion of Byzance après Byzance (1935) which brilliantly exemplifies the synthesis of universal and national history through the mediation of regional history. On the one hand, it postulated the belonging of the SoutheastEuropean peoples to a universal civilization bridging the East and the West yet being neither of the two, possessing a unique ecumenical role and a unique contribution to world history. On the other hand, it stressed the idea of Byzantium's spiritual and institutional continuity through the Romanians once the empire had ceased to exist politically - an idea also expressed in his History of the Balkan States in the Modern Age (1913). "There was a time," Iorga contended in the introduction to his latter book,

when it appeared that the entire Byzantine, Balkan legacy should be inherited by our [Romanian] princes who (...) showed that they wanted to preserve it and that they were capable of sacrificing themselves for it. (...) For five hundred years we had given asylum to the whole higher religious life, to the whole cultural life of the peoples from across the Danube. The Greek Byzantium and the Slav Byzantium, which derived from it, had thus lived for another half millennium among us and through us, if not for us...(Iorga 1913: 8, 11)

It was the wreaking of a place for the Romanite orientale in the world history - an effort crowned by his monumental La place des Roumains dans l'histoire universelle (3 Vols., 1935-36) - that led Iorga to elaborate on the historical continuity and cohesion of Southeastern Europe.

Instead of civilizational discontinuities and ethnic fragmentation, as Cvijić was intimating, the region came to be distinguished by a "synthesis of a completely particular character common to the whole South-East of Europe," which furnished the 
"base of its common elements" (Iorga 1935: 110). The primary, "prehistoric" element of this synthesis, and one "which distinguishes the East from the European SouthEast," were the Thracians, who were "at the origin of everything in the European South-East" (Iorga 1935: 115; Iorga 2008: passim). "We can say that even today, in Southeastern Europe, there are millions of crypto-Thracians, people who speak different languages, believed to belong to completely distinct nations, that is to say, which have their history, their ethnographic if not ethnological character, and [who] nevertheless belong at the same time to that great race, whose history unfortunately had not [yet] been written but by philologists" (Iorga 1935: 115).

The second element of the synthesis was the Roman layer. The regional network of cities, fortresses, routes and markets - and the interdependence which they sustained - "are not, still at present, but the continuation of the old establishments, in which the Thracian element was transformed under Roman influence" (Iorga 1935: 120121). That Roman "order" was continued by a "neo-Roman" one - Byzantium. With one important difference: while the Romans effectively governed, the Byzantines "had left to the populations the right each to live in its own country, according to its habits." 19 The Ottoman Turks carried on the latter tradition: "the conquerors ... became the continuators of the Byzantine empire, with the same mixture of centralism and local freedom for all the peoples in this region" (Iorga 1935: 123). If that "formă de universalitate" which Byzantium presented ${ }^{20}$ could survive until the nineteenth century, Iorga contended, it was due to the Ottomans - "not [...] the destructors of the Byzantine empire, but its continuers." Peace, local autonomy and opportunities for the small nations, which these two empires had ensured, made possible the endurance of that "unity in diversity" which came to distinguish the region (Iorga 2000: 71-88; Iorga 1940: 14).

Consequent to this genealogy of the region's unity, Iorga sought to dispel the idea of the "Oriental Southeastern Europe" as being either markedly Oriental, or indeed worthy of scorn for being as Oriental as it was. In his own time he discovered many more vestiges of the prehistoric and classical legacies, e.g., art, dress, rituals and customs, than of the Orient. The "deep realities below the upper social layers" and the "popular life" across the whole region "were very little affected by the oriental influence." Eastern Orthodoxy itself was "much more a religion of pagan European superstitions and rationalist Greek interpretations than of myths coming from Asia... The orthodox religion, I say, does not possess the entire oriental mystique: within it there exist elements with origin in a much deeper local past" (Iorga 1935: 117). Populations coming from the Asian steppes had been completely assimilated by the indigenous peoples. As for the Ottoman Turks, not only had they borrowed heavily from the Roman/Byzantine institutions, but in racial terms they "had always been

19. “Byzance n'est point autre chose que la souveraineté romaine de jadis... ; tant qu'a duré l'Empire byzantin, dont l'utilité a été immense, cet ordre romain est resté immuable, les éléments d'adaptation, d'emprunt, aux différentes époques ultérieures, s'y ajoutant seulement" (Iorga 1935: 121-22).

20. Defined "as a complex of institutions, a political system, a religious formation, a type of civilization, comprising the Hellenic intellectual legacy, Roman law, the Orthodox religion, and everything it created and preserved in terms of art" (Iorga 2000: 25). 
a minority in Southeastern Europe," their racial make-up having been thoroughly altered by the massive 'infusion' of local blood (Iorga 1935: 117-118). ${ }^{21}$

Iorga's Southeastern Europe thus differs considerably, and not only geographically, from the Balkans of Shishmanov and Cvijić. For the first time, the existence of a "fundamental unity resting on archaic traditions" is postulated. A "particular [culture] common to the whole European South-East," a shared racial nexus, and a peculiar historical, ethnographic and cultural "synthesis" between all those peoples is formulated: "The whole European South-East forms, in a certain sense, the same country, is the same territory, with the same memories - an integral world... [...] Everything connects us beyond our will" (Iorga 1940: 12,14). Rather than presenting the sum total of ethnic essences marked by external borrowings (Shishmanov) or migrations (Cvijić) - in other words, rather than being 'nationalized' - the Balkan nations came to be 'Balkanized' by way of being endowed with a common heritage distinguished by specific historical evolution, life forms and culture. This specificity, drawing upon the great Thraco-Illyrian-Roman tradition and epitomized by Byzantium, was taken over by the Ottoman Empire and constituted the heritage that the Balkan peoples shared. All of them - Greeks, Bulgarians, Serbs, Romanians, Albanians, and Turks - had been subject to the same great Western, Eastern, racial, and religious influences. Where Cvijić saw discontinuity between the Roman, Byzantine, and Ottoman 'layers' of history, Iorga saw 'in essence the same thing: the same peace, the same liberties with respect to the small groups, the same routes created for great commerce" (Iorga 1940: 11). Precisely where ethnographers and anthropogeographers tended to identify a great diversity of local variants and discrete factors, Iorga saw cross-regional kinship and permeability to the point of indistinctiveness: in the outlook of the village, in houses (except the Mediterranean one) and their internal arrangement, in essential elements of vestment, in racial fundament, in popular poetry, dances and superstitions, in customs and mores, in way of thinking and sentimentality, and - most strikingly - in institutions (royal, administrative, judicial, fiscal, military, social) (Iorga 2008: 7-14, passim). Interactions between the Balkan peoples were crucial for Iorga too, but not in the sense of contacts between distinct albeit closely connected groups, but as virtual acts of "coming home" whenever and wherever in the region they took place. ${ }^{22}$ Remarkably, Iorga sought to dispel the Slavic world as a 'rival' symbolic historical region: a Serb, he argued, had much more in common with an Albanian or a Romanian, than with a Czech.

It would nevertheless be misleading to presume that Iorga's interlocking projections were only scholarly variations on a political tune. They were no doubt political: the institutionalization of Southeast-European studies in Bucharest and the regional re-positioning of the Romanian past were meant to underwrite Romania's growing

21. “Il n'y a pas de people cohabitant, avec une caractère de culture propre, qui n'ait transformé des Turcs" (Iorga $1935:$ 122).

22. For example, the Bulgarian clergy and the fighters for a Bulgarian state, who had found asylum among the Romanians north of the Danube, "had the right to come here, where, due to the old-time fundamental unity resting on archaic traditions, they were at home," as were the Phanariots who had not come to Romania as Greeks but wanted to become Romanians (Iorga 1940: 12, 13-14). 
political weight in the area after the Balkan wars (1912-13). ${ }^{23}$ But both conceptually and as historical schemata, they were more complex and elaborate than those of the bulk of nation-building historians at the time.

Aligning himself, in the vein of Lamprecht's global vision of historical phenomenology, with the new cultural history, Iorga upheld an emphatically organic conception of the historical evolution of humankind. In the perspective of the latter, the understanding of the history of an individual nation could not be achieved by studying it independently. The peoples, being "necessary, permanent and, in a certain sense, eternal creations," encroached on, transferred to, borrowed from, conquered and were subdued by each other. Resonating Shishmanov's views, Iorga asserted that this process of continuous interaction had totally changed the understanding of the notion of people. It was not the pure and self-contained entity of the Romantic period anymore, but a natural whole with its own organic life, similar to the life of individuals: it grew by what it gained from outside, it got cleansed and rejuvenated by what it gave up after a certain time, it died and was resurrected. What ultimately defined a people's power and value in the world was "that inherent, elemental energy, which determines its potential to assimilate and to radiate, and the proportion in which it abandons its worn-out elements" (Iorga 1911: 14-15).

A striking consequence of this approach was the "disappearance of the distinction between world history and national history," since

The life of a people is continuously enmeshed with the lives of other peoples, depending on and continuously influencing them. Each nation is an energy with its own sources and particular circumstances, its special character and mission. But none of these energies can be absolutely isolated for study and must not be isolated in this way. All these intersecting streams function in the same atmosphere and flow on the same earth [...]. The history of a people, thus, touches the history of others, not through fleeting mentions or short chapters about reciprocal influences, but is established and preserved in the natural medium of human universality, to which it belongs in its highest essence. And universal history, in turn, is not anymore (just) a collection of national histories, clustered by geographic or cultural criteria, but the study of those connections of cultures, political ideas, expansions and conquests on all terrains, transfers, transformations, reinforcements and enfeeblements, which should alone be its domain - one that is sufficiently 'scientific' and 'philosophic' as to leave no space for any other science or philosophy of history. (Iorga 1911: 17)

As a Lamprechtianist and participant in Lamprecht's project of Weltgeschichte, Iorga was thus most concerned with situating Romanian history into universal history. In this spectacular scheme, the region was assigned a key role as it came to stand as a mediating zone and a condition for global integration.

Special mention in this direction is due to his ethno-populist narrative of the Balkan peasantry and the "spiritual life of the village" as the ultimate repository of a nation's distinctive culture - of its "ideas." The latter was one of the three "historical permanencies" - the other two being "soil" and "race" - which, in contrast to the

23. On the way Iorga's system of political values had construed his historical knowledge through strictly scientific researches, see Pearton (1988) and Pippidi (1991). 
constant flux of events, traversed time and space and determined "all 'pragmatic' history" (Iorga 1999: 271-282). Permanencies, once again, manifested themselves on two levels: in Iorga's phenomenological perspective they underlay the unity and the continuity of a Southeast-European "form of civilization," but in their specific blends transformed into the mainstay of national authenticity.

In many ways, Iorga's regionalist projections were groundbreaking. They came closest to defining the region in terms of legacy of a common past, hence of shared structures and attitudes. For this reason, imperial frameworks were essential in his regional vision. But the latter also fused a series of contradictory dimensions as regards the connection between the national, the regional, and the universal, scholarship and politics, evolutionary and presentist perspectives, methodological subjectivity and positivism, 'nostalgia for totality' and obsession with Romanianism. At a certain juncture in his historiology, the polymorphism of the Southeast-European region succumbed to a deeper common factor - the popular rural institutions (Iorga 2008), while geography ("soil") ever imposed itself. However, the structural and explanatory conceptual tool for him was neither 'law' nor 'structure' but supra-institutional culture - the persistence of collective ideas, ways of thinking and instinctive behavior that furnished the continuity and the organic unity of history across space and time.

We should be aware moreover that both Cvijić's and Iorga's positions need to be seen in their historical dynamics as they shifted considerably over time. Cvijić's position evolved from narrowly pro-Serbian at the beginning of the 20th century to patently pro-South Slav (and anti-Bulgarian) during the First World War, and especially around the Paris Peace Conference, to once again "pro-Dinaric" and "antiPannonian" in the 1920s. Iorga's position also evolved from more squarely nationalist in the 1910s to more 'internationalist' and 'Southeast-European' in the 1930s. But, generally speaking, his chronological evolution was less neat, often mixing in parallel or even in the same text different registers and paradigms. All in all, the co-existence of scholarly and para-scholarly registers was characteristic of interwar Balkanists - from Cvijić, Gesemann and Iorga to the relatively most sophisticate school of Balkanology in the 1930s.

\section{Balkan organism and homo balcanicus: the interwar "Balkan science"}

The 1930s and the first half of the 1940s saw the crystallization of a more rigorous and systematic research program for the region of Southeastern Europe even if, on the whole, the national framework retained its powerful position. The initial attempt at defining the new "science of Balkanology," as it was called, belongs to the two editors of the Belgrade-based Revue Internationale des Etudes Balkaniques - the Croat Petar Skok (1881-1956) and the Serb Milan Budimir (1891-1975), both of them philologists and classicists. ${ }^{24}$ It was aimed at elucidating regional commonalities while "drawing upon the comparative method of the nineteenth century," and pointing national

24. Not surprisingly, this "pan-regional" agenda, and a number of institutional venues supporting it, had an immediate political incentive: they emerged simultaneously with or briefly after the conclusion of the Balkan pact in 1934. 
academic research "towards the study of a Balkan organism that had constituted one entity since the most distance times" (Budimir \& Skok 1934: 2-3).

Two historical tendencies - unification and particularism - are said to have crystalized into "a unique law of the Balkans [loi balkanique] guiding the vicissitudes of the total of their history." Since Antiquity, these two tendencies have alternated and defined the peculiar evolution of this region. The major forces of "Balkan aggregation" were the Macedonian dynasty, the Romans, the Byzantine Empire, and the Ottoman Empire. Significantly, the role of the "Turks" in imposing social and cultural cohesion on the whole region was seen to be the most salient. Echoing nineteenth-century romanticism, modern science very often misinterpreted the results of the aggregation which they achieved, and refused to see what was beneficial in a regime which had never implemented a denationalizing policy characteristic for many European states.

The spheres where the two Balkanologists found the unifying impact of the Ottomans to have been most consequential for the future "regional aggregation" are worth noting. First, by imposing the same political and social conditions, the Turks had effectively amalgamated the mentality of the Balkan peoples. At the same time, the mixture of Balkan races had to some extent effaced the mental differences which the previous particularist medieval states had induced. Another unifying factor was the introduction of "Oriental urbanism" - the Balkan city created by the Turks which was "totally different from the ancient and the European." Remarkably, even folklore, and popular literature generally, were found to be the product of the "Turkish unification:" "Among all those peoples, the period of Turkish domination had stimulated the blossoming of national epopees [which are] major sources of pride for these peoples." Popular poetry, furthermore, travelled freely across the Turkish realm creating common themes and vocabularies. It was to the Turkish regime, again, that the Romantic literary movement, the "Balkan Romanticism," owed its special complexion, so different from those of European romanticisms. Finally, it was utterly erroneous to consider the Turks hostile to the civilization created in the Balkans before them since their empire had maintained a number of Byzantine institutions (Budimir \& Skok 1934: 5-6, 12).

Here we can see some of the central arguments of the preexistent Balkan scholarship, as developed by Shishmanov and Iorga, being brought to their logical completion. Individual Balkan renascences, and quite nearly national "individualities" themselves, became conceivable only in the framework of the Ottoman Empire. At the same time, the whole Romantic structure of nationhood in its Eurocentric mold was turned on its head without however subverting the state-building project as such.

Skok's and Budimir's programmatic statement presents the first attempt of formulating the methodology of a "new science" intended "to define and explain the parallel facts that make themselves manifest in the different domains of human activity in the Balkans." To this end they suggested a division of labor: the study of only what is specific to a given people should be left to the specialists in the national sciences. This did not imply a rift between regional and national scholars as it was from the latter that regionalists would extract information from the national sciences, their work presenting a "superior interconnectedness" by means of interBalkan comparisons. A series of examples were adduced in support of the contention 
that a Balkan perspective alone was capable to shed proper light on major historical processes which, when being placed in a strictly national framework, remained incomprehensible. In sum,

... Balkanology appears as an immanently comparative science. In essence it represents a system of inter-Balkan comparison whose main objective is to reveal, understand and define the Balkan reality such as it has manifested itself, across time and space, in the various spheres of human activity. To get to know what was and is typical of the Balkans, such is the object it envisages for itself. (Budimir \& Skok 1934: 23-24)

This Balkanology had two facets - theoretical and practical. "As a theoretical science [Balkanology] is called to deepen our knowledge about the relations between the Balkan peoples and throw light on the intrinsic laws which had governed and continue to govern their development and their life." As a practical science, it was of moral importance. It was "entitled to influence the Balkan mentality" by giving the Balkan statesmen the opportunity to know the Balkan man, his natural and social environment, way of thinking and feeling, and, at the same time, by teaching the Balkan communities the necessity to know, understand, and cooperate with each other (Budimir \& Skok 1934: 24-25).

This Balkanological manifesto was not only the first of its kind. But also, laterday Balkanistics would have, as it turned out, little to add to the theoretical and methodological conceptualization of the field. Balkan comparatism, as conceived here, was not just a multi-disciplinary and problem-oriented exercise. It evolved in two interdependent directions: as a study of "mutual influences" and exchange between national entities ("transfer history') and of "common Balkan traits" or "Balkan peculiarity" ('transnational history'). Balkanology was meant to deal with the general, the syncretic - the "Balkan reality," the "Balkan man," the "Balkan organism" and its "characteristic laws" - not with the nationally specific. It came up with a research agenda and a method aimed at a regional "synthesis drawing on the elements of Balkan interdependence and unity" (Papacostea 1938: vi). This, at the same time, did not undermine ethnic and national frameworks: the actual historical actors were, invariably and self-evidently, the Balkan peoples, if not always the Balkan states.

Proceeding from the notion of 'Balkan organicity' and the Balkanological 'curriculum' of his Yugoslav predecessors, the founder of the Bucharest-based Institute for Balkan Studies and Research in 1937, Romanian medievalist Victor Papacostea (1900-1962), left us perhaps the most radical assertion of what he called the "impossibility of studying the life of any Balkan people separately" and of the imperative for a transnational and multidisciplinary approach to the past of this part of Europe (Papacostea 1996, 1938, 1943). "Determined in its investigations by the frontiers fixed by geography and history, Balkanology," Papacostea re-affirmed, "aims at revealing the characteristic laws and circumstances, under whose operation there has developed, century after century, the life of the Balkan peoples, in its whole and for each of them." More radically however, Papacostea considered the adoption or forced imposition of the very idea of the nation-state, one that was "created in the West and for the West," to have had catastrophic consequences in the Balkans a region that, unlike Western Europe, was marked by a unity of economic geography, by "the 
same community of culture and civilization born by long coexistence," and by being "in the main subordinated to the same political systems and influenced by the same currents of ideas." Above all it was the "common ethnic base" and the "millennia-long mixture of races that has resulted, ever since antiquity, in the strongly relative value of the idea of nationality in the Balkans."

Papacostea spoke instead of a "Balkan nationality" and "Balkan society" as well as of a "homo balcanicus" - a syncretic type defined by complex ethnogenesis, mental and spiritual structures and linked to, above and beyond his native and linguistic group, "the great Balkan community through organic links coming from a complex and lengthy ancestry." Under such conditions the idea of nationality remained precarious and uncertain, "in reality a notion, not ethnic, but mostly political and cultural," whereas one realized "how intensive the exchange of influences among these peoples was and how easily important elements of culture and civilization passed from the one to the other. But above all: how misplaced and ridiculous appear the exaltation of national particularisms."

One of the striking facts about this methodologically sophisticate regionalism that blossomed in the 1930s is the rehabilitation of the term (region) of the Balkans - to the extent that Papacostea, who, in the vein of Iorga, deeply disagreed with such a regional denomination, saw himself compelled to surrender to the impossibility of replacing it. There are, it seems, two major reasons, whose combined effect could help us explaining this trend. One was the ascendancy of the Nazi-German re-definition and argumentation of Southeastern Europe as a geopolitical and economic space, distinct from the 'historical Balkans,' which exposed even more starkly than before the vulnerability of a small-state region. The other was the urge to counteract the, what Budimir and Skok dubbed, "general misunderstanding of all things Balkan" by asserting the existence of a unique Balkan world with a distinctive yet universally significant culture, and a peculiar Balkan man with his own spirituality and sensitivity. ${ }^{25}$ Thus, as it happened, the same regionalist scholars operated, in parallel if not in the same texts, on another 'Balkanistic' register, employing quasi-academic and metahistorical arguments to underwrite a notion of 'Balkanism' closely replicating national autochthonism.

More radically than Iorga, interwar Balkanologists 'redeemed' the region by pushing it into the symbolic space traditionally occupied by the nation. They embarked on vindicating the "strong and irreducible Balkan individuality," which they saw as a token for the region's "historic function" of mediating between the East and the West, the eastern and the western Mediterranean, the ancient and the modern world, and for its creative potential: "what it had generated by its own forces in order to lay it at the disposal of Europe" (Budimir \& Skok 1934: 19). The tendencies of unification and particularism were now transfigured into "the two most precious elements" which "the Balkan man" had granted to human progress: "the spirit of independence [samosvojnost] (= individualism) and the spirit of association (= collectivism)." The

25. It should be noted that the German Byzantine and Slavic studies of the previous decades, not solely local incentives towards such redefintion, had helped prepare the grounds for such a "rediscovery" of the Balkans. 
harmony of individualism and collectivism were said to be the hallmark of regional history since Antiquity. Unlike "Pax Romana" with its "uniform unity," the Balkans of both the Byzantine and the Ottoman eras "tended towards unity in variations, a diverse unity." "The varied commonality is more efficient and more durable than the uniform unity, the organized variety having, properly speaking, bigger 'biological' value than the unity without variations." Thus, instead of treating it as a "European anomaly," as the conventional Western wisdom had done, the Balkan diversity and "melting pot" were revalorized as a source of generative power: "All in all, the Balkans is the genuine cradle of humanism [čojstvo] and heroism. These are the principal characteristics of the Balkan mountaineer and also the true ideas of a sincere humanism. They had preserved the Balkan people [Balkanci; les Balkaniques] throughout all the centuries of grandeur and sufferance". (Skok \& Budimir 1936)

As to the 'immanent' regional violence, that proverbial Balkan vice, it was asserted to be utterly alien to the local tradition and imposed from the outside. It had made its inroads during the Balkan "Risorgimento," when a major "re-orientation of the Balkan civilization" took place: the Oriental culture in its Islamic form gave way to the Western culture based on scientific and technological progress. It was at this juncture that the Balkan scholars saw the source of a major historical regression: all previous civilizations - the Hellenistic, the Roman, the Byzantine, the Ottoman had brought unity to the region, "while modern European culture during the Balkan Risorgimento, on the contrary, divided politically and morally the inhabitants of the Peninsula at the same time as it leveled them through its cultural influence."

The culmination of this line of reasoning was the entreaty that "the Balkans itself should define its proper cultural orientation ... in view of creating on these bases a better common Balkan fatherland [patrie balkanique commune]..." Throughout all its great epochs the peninsula had had its authentic spiritual orientation, which made itself manifest in "a sort of homogeneity unique to the Peninsula." Rather than spontaneously springing from an ancient tradition, however, such a "Balkan spirit" could take root among the peoples in the region only through the sustained efforts of the post-war generation. In conclusion,

This Balkan spirit demands first of all that the whole spiritual and material civilization, such as it has emerged in the Balkans, should be envisaged, criticized and organized not in view of Western Europe but, above all, in view of the needs of the Balkan fatherland taken as one whole. (Skok \& Budimir 1936)

So, a new authentic spirit, regenerated and elevated to a new level, a new sense of a pan-Balkan fatherland, a new Balkan culture based on a long-standing tradition of unity in diversity, regional self-reliance and self-sufficiency - these were the key concepts on which the politics of the 'new Balkan science' were made to rest.

All this resonates intimately with the prevailing 'nativist' currents and autarchic thrusts in nationalist political and intellectual thought of the late 1920s and the 1930s, captured by calls for resurgence of national authenticity and self-sufficiency. It is telling that the impulse to transpose national autochthonism onto Balkan autochthonism had spilled far beyond the Balkanologist scholarly circle and had come to buttress different cultural-political projects. Thus the Bulgarian historian of culture Naiden Sheitanov pled for the resurgence of "the ancient-Balkanic" and "the Thraco-Balkanic," as 
epitomized by Orpheus and Dionysius, and for the creation thereby of "Thracianism as a culturally-regenerating direction" to the future of the Bulgarians (Sheitanov 2006). Discussing the Balkan Christians' awareness of "their civilizational Christian mission" and the existence on this basis of a Balkan "cultural and spiritual oecumene" during the late Middle Ages, the Croatian philosopher and ethno-psychologist Vladimir Dvorniković asserted that "already at that time there existed a 'Balkan soul,' only that it did not yet speak in a political language" (Dvorniković 1936). The Balkans in the cartography of the Bulgarian philosopher Janko Janev was not a geographical notion but a place that had become destiny: he saw it as the bridge to the "worldhistorical becoming," the zone where the fate of the West will be sealed (Janeff 1936: 7-9). In an interesting inversion of Iorga's symbolic map of extra-regional orientations and Cvijić's stigmatic characterology of the Bulgarians' immanent Balkanness, Janev identified only the Bulgarians and to some extent the Serbs, by virtue of their jovial archaic disposition, as the par excellence Balkanites and authentic Balkan peoples, whose "barbarity" boded their spectacular renaissance. ${ }^{26}$ The Serbian poet Rade Drainac came up with a "Manifesto of the Balkan Culture" bitterly attacking the "inhuman Western culture," the "soulless industrialism" and "radical realism" of the West, which threatened to "kill the human soul and will destroy humankind." He appealed for the creation of a "new civilization" and a "more humane culture - a Balkan culture," marked by "superior ethics" and "more humane morality," by way of "boycotting forever the systems [promoting] materialistic and mechanic worldviews" (Drainac 1931). ${ }^{27}$

The Balkan scholars did not as a rule go that far in their anti-Western rhetoric. But the similarity in binaries (the materialistic/inhuman West vs. the spiritual/humane Balkans), concepts (independence, ethics, regeneration, mission) and orientation is significant. As are the differences: rather than insisting on safeguarding the Balkans from the "contaminated West" by surrounding it with a Chinese wall, as Drainac did, the Balkanists proposed to "save" civilization by fertilizing the West's technical progress with the Balkans' spirituality and humane ingenuity:

The empire of Americanism and technique cannot be maintained unless it concludes a durable union with the empire of humanism and the spirit, whose thrones had been occupied by so many sons of the Balkan land, a mountainous source of cosmic and human forces. One of the Balkan destinies resides, it seems, in that these peoples could also lay down the conditions for a harmonic fusion of Americanism and humanism, a harmony which the present-day humankind clearly feels a need for". (Skok \& Budimir 1936: 612-13)

In many ways the regional level in the writings of that time exhibits the features of methodological nationalism - a sort of national autochthonism writ large. For some

26. According to Janev, the Romanians were alien to the Balkan spirit by virtue of their "a-national" intelligentsia which served politically the French; the Turks had no historical roots in the region; while the Greeks had lost their one-time specificity being neither Apolonic nor Orphic (Janeff 1936: 117-118).

27. The manifesto was dispatched to and published by a number of newspapers in the region and beyond. 
this was a reaction to the awareness of frail state sovereignty; for others, an exertion to combat the nation's symbolic underdog position by the proxy of regional dignity. Some extrapolated the national ontology and organicity onto the region, others assimilated the region's "cosmic" forces, mythical substrata and "world-historical vocation" into the national discourse. The upsurge of regional schemes during the interwar period is related to a certain anti-hegemonistic resistance which, ironically, made itself manifest in both autochthonist and regionalist directions. The striking common feature of both, however, was the complete volte-face which the valency of the Balkans - and of being Balkan - had undergone in the 1930s. This new notion of Balkanness endeavored, and apparently succeeded, to indigenize and devour the historical teleology and the cultural mission of Europeanness.

\section{Conclusions}

A striking common feature of the supranational projects discussed here, and others which were not discussed, is the ambiguous entanglement of the national and the transnational: these projects could erode but also buttress national differences. For none of our scholars did the "Balkan idea" imply obliteration of the national; at the same time none deemed it to be just the sum total of its constitutive nation-states. No one expressed this ambiguity better than Iorga:

On parle aujourd'hui très souvent, presque à toute occasion, d'un internationalisme, qui ne signifie en fait que s'entre tolérer [...] Ce qu'il faut c'est autre chose : revenir par l'interpénétrations aux vieilles unités morales. Pour cela, il n'y a rien à sacrifier dans ce qui nous est le plus cher. Les nations sont des organes ayant leur rôle autonome, mais ceci ne dénie pas la nécessité de l'organisme unitaire, qui vit d'autant mieux si cette autonomie se conserve saine et pure. (Iorga 1929 : 136)

The very relationship of the "organs" to "organism," on the other hand, considerably changed the understanding of the national. The nation-centered paradigm was strongly relativized when ensconced in the 'supranational' cultural-historical environment of the region. The Balkanologists sought to reformulate the nationalist semantic framework whereby the proper understanding of one's nationality and true patriotism would entail the acknowledgment for their transnational embedment. "Our patriotism, if it wants to be real, should be a Balkan patriotism," asserted the founders of the Belgrade Balkan Institute (Parežanin \& Spanaćević 1936: 321). In many ways that was a 'methodologically national' regionalism: the Balkans was envisioned as an overarching quasi-nation, and Balkanness as the quintessence of the unique and deep-seated ethno-cultural and ethno-psychological traits of the national character. In the heyday of European nationalism, national autochthonism and Balkan regionalism were as closely fused as they had never been before or after that.

A sense of geopolitical vulnerability had much to do with all that: transposing or relegating sovereignty on the region was seen as a way of offsetting the impotence of small statehood in the geopolitical ambiance especially of the 1930s. "The Balkans to the Balkan peoples" was an age-old outcry against both imperialist encroachment and intraregional strife. But these were political contingencies which, next to the low level of institutionalization of regional studies relative to the nation-centered disciplinary 
canons, boded badly for the establishment of a continuous - stable and strong tradition of Balkanology.

Yet, as this essay has attempted to intimate, it is not enough to evaluate the politics of 'Balkan science' in view of its lost battle against methodological and geopolitical nationalism. On a certain level, the region provided a frame for posing critical questions about modernity and negotiating the nation's relationship to the transnational cultural, social and economic processes. The discourse of regionalism, in this sense, provided the symbolic language to think about identity and change. On another level, these supranational constructs bring up the issue of the categories we can convincingly use in conceptualizing space beyond the nation-state - a question not answered yet in empirical if not theoretical sense. Here, again, the concepts of the Balkans which had emerged since the late $19^{\text {th }}$ century have some meaningful things to tell us. It is hackneyed and unproductive to see them as simply the manifestations of small-culture syndrome or responses to western Balkanism. Present-day analysts dealing with these issues would do better to take them seriously, in their own terms and right.

\section{References}

Bakić-Hayden, Milica, 1995. "Nesting Orientalisms: The Case of Former Yugoslavia,” Slavic Review 54(4): 917-931.

BoGDAN, Ioan, 1905. Istoriografia romană și problemele ei actuale. București: Institut de Arte Grafice Carol Göbl.

Braudel, Fernand, 1995. The Mediterranean and the Mediterranean World in the Age of Philip II. Berkeley and Los Angeles: University of California Press.

Budimir, Milan and Petar Sкок, 1934. "But et signification des études balkaniques," Revue internationale des études balkaniques 1: 1-28.

Cvisić, Jovan, 1918. "The Zones of Civilization of the Balkan Peninsula," Geographical Review 5(6): 470-482.

-, 1922. Balkansko poluostrvo i južnoslovenske zemlje I. Zagreb: Hrvatski Štamparski Zavod.

-, 1931. Balkansko poluostrvo i južnoslovenske zemlje II. Zagreb: Hrvatski Štamparski Zavod.

Ćorović, Vladimir, 1937. Borba za nezavisnost Balkana. Beograd: Balkanski institut.

Drace-Francis, Alex, 2003. Zur Geschichte des Südosteuropakonzepts bis 1914," in Karl Kaser, Dagmar Gramshammer-Hohl and Robert Pichler (eds.), Wieser Enzyklopädie des europäischen Ostens, 11: Europa und die Grenzen im Kopf, 275-286. Klagenfurt-Celovec: Wieser Verlag.

Drainac, Rade, 1931. “Manifesto of the Balkan Culture,” Literaturen glas, IV (135): 1-2.

Duțu, Alexandru, 1999. Idea de Europa şi evoluţia conștiinței europene. București: All.

Dvorniković, Vladimir, 1936. "Der kulturhistorische Geist des Balkan," Revue internationale des études balkaniques II (4): 431-436.

Freeman, Thomas, 1967. The Geographer's Craft. Manchester: Manchester University Press.

Friedman, Victor, 1994-1995. "The Place of Balkan Linguistics in Understanding Balkan History and Balkan Modernity," Bulletin de l'Association des études du sud-est européen 24-25: 87-94.

-, 2006. "Balkans as a Linguistic Area," in Keith Brown (Editor-in-Chief) Encyclopedia of Language \& Linguistics, Second Edition, 1: 657-672. Oxford: Elsevier. 
-, 2007. "Balkanizing the Balkan Sprachbund. A Closer Look at Grammatical Permeability and Feature Distribution," in Alexandra J. Aikhenvald and Robert M.W. Dixon (eds.), Grammars in Contact: A Cross Linguistic Typology: 201-219. Oxford: Oxford University Press.

Gesemann, Gerhard, 1943. Heroische Lebensform: Zur Literatur und Wesenskunde der balkanischen Patriarchalität. Berlin: Wiking-Verlag.

Goldsworthy, Vesna, 1998. Inventing Ruritania: The Imperialism of the Imagination. Yale: Yale University Press.

Guyau, Augustin, 1913. La Philosophie et la sociologie d'Alfred Fouillée. Paris: Alcan.

IORDANOV, Veliko, 1938. Laipcig i balgarite. Sofia: n.p.

IORGA, Nicolae, 1911. Două concepţii istorice. Burureşti: Inst. de Arte Grafice Carol Göbl.

-, 1913. Istoria statelor balcanice în epoca modernă, Vălenii-de-Munte: Neamul Românesc.

-, 1914. "Inauguration de l'Institut. Discours du professeur N. Iorga (24 janvier n. st.)," Bulletin de l'Institut pour l'étude de l'Europe sud-orientale, Bucarest I (2).

-, 1929. Etudes byzantines, vol. II. Paris: Librairie universitaire J. Gamber.

-, 1935. "Eléments de communauté entre les peuples du Sud-Est Européen," Revue Historique du Sudest européen 12(4-6): 107-125.

-, 1940. Ce este Sud-Estul european. Bucureşti: Datina Românească.

-, 1999. Generalităţi cu privire la studiile istorice [4th ed.]. Iaşi: Polirom.

-, 2000. Byzantium after Byzantium (transl. L. Treptow), Iaşi, Oxford, Portland: The Centre for Romanian Studies [originally published in 1935 in French, Byzance après Byzance. Continuation de l'Histoire de la vie byzantine]).

-, 2008. Caracterul comun al instituțiilor din sud-estul Europei. București: Editura Valahia (originally published as Le Caractère Commun des Institutions du Sud-Est de l'Europe. Paris : Librairie universitaire J. Gamber, 1929).

JANEFF, Janko, 1936. Der Mythos auf dem Balkan. Berlin: Verlag für Kulturpolitik.

Kaser, Karl, 2003. "Peoples of the Mountains, Peoples of the Plains: Space and Ethnographic Representation," in Nancy M. Wingfield (ed.), Creating the Other. Ethnic Conflict and Nationalism in Habsburg Central Europe, 216-230. New York-Oxford: Berghahn Books.

Kopitar, Jernej, 1829. "Albanische, walachische und bulgarische Sprache," Jahrbücher der Literatur 46: 59-106.

LeSkien, August, 1925. Balkanmärchen aus Albanien, Bulgarien, Serbien und Kroatien. Jena: Diederichs.

Miklosich, Franc, 1861. "Die slavischen Elemente im Rumunischen," Denkschriften der Kaiserlichen Akademie der Wissenschaften, Philosophisch-historische Klasse 12: 1-70.

Papacostea, Victor, 1938. “Avant-Propos,” Balcania 1: iii-vii.

-, 1996. "Balcanologia," Sud-Estul și Contextul European 6: 69-78.

-, 1943. "La Péninsule Balkanique et le problème des études comparées," Balcania 6, iii-xxi.

Parežanin, Ratko and Stojan Spanačević, 1936. "Der neue Balkan," Revue internationale des études balkaniques II (4): 321-332.

Pearton, Maurice, 1988. "Nicolae Iorga as Historian and Politician," in Denis Deletant and Harry Hanak (eds.), Historians as Nation-Builders: Central and South-East Europe, 157-173. Seattle and London: University of Washington Press. 
PIPPIDI, Andrei, 1991. "Reformă sau declin. A doua periodă a studiilor sud-est europene în Romănia," Revista istorică 2(11-12): 641-650.

Roucek, Joseph, 1939. The Politics of the Balkans. New York: McGraw-Hill Book Co.

SAndFeld, Kristian, 1930. Lingustique balkanique. Problèmes et résultats. Paris: Klincksieck.

Sheitanov, Naiden, 2006 [1939]. Balkano-balgarskiat titanizam. Sofia: Zaharii Stoianov.

Shishmanov, Ivan, 1965. Izbrani sachinenia, I. Sofia: Izdatelstvo na BAN.

-, 1966. Izbrani sachinenia, II. Sofia: Izdatelstvo na BAN.

Sкок, Petar and Milan Budimir, 1936. "Destinées balkaniques," Revue internationale des études balkaniques 2 (4): 601-612.

Stadtmüller, Georg, 1950. Geschichte Südosteuropas. München: Oldenbourg.

Todorova, Maria, 1997. Imagining the Balkans. New York-Oxford: Oxford University Press.

TrendafiLov, Vladimir, 1996. Neizlichimiat obraz v ogledaloto. Sofia: Kralica Mab.

Trubetzkoy, Nikolai, 1923. "Vavilonskaja bašnja i smešenie jazykov,” Evrazijskij vremennik 3: 107-124.

-, 1933. « La Phonologie actuelle », Journal de Psychologie, 1-4: 227-246.

VAlJaVec, Fritz, 1941. "Der Werdegang der deutschen Südostforschung und ihr gegenwärtiger Stand," Südost-Forschungen 6: 1-37.

-, 1942. “Südosteuropa und Balkan,” Südost-Forschungen 7: 1-8.

Weigand, Gustav, 1925. “Vorwort, zugleich Programm des Balkan-Archivs,” Balkan-Archiv. 1: V-XV.

Žıvković, Marko, 1997. "Violent Highlanders and Peaceful Lowlanders. Uses and Abuses of EthnoGeography in the Balkans from Versailles to Dayton," Replika: 107-120. 